\title{
Host and geographic range extensions of the North American strain of viral hemorrhagic septicemia virus
}

\author{
R. P. Hedrick ${ }^{1, *}$, W. N. Batts ${ }^{2}$, S. Yun ${ }^{1}$, G. S. $\operatorname{Traxler}^{3}{ }^{3}$ J. Kaufman ${ }^{4}$, J. R. Winton ${ }^{2}$ \\ ${ }^{1}$ Department of Medicine and Epidemiology, School of Veterinary Medicine, University of California, Davis, \\ California 95616, USA \\ ${ }^{2}$ Western Fisheries Research Center, 6505 NE 65th Street, Seattle, Washington 98115, USA \\ ${ }^{3}$ Pacific Biological Station, Department of Fisheries and Oceans, Nanaimo, British Columbia V9T 6N7, Canada \\ ${ }^{4}$ Oregon Department of Fish and Wildlife, Department of Microbiology, Oregon State University, Corvallis, \\ Oregon 97331, USA
}

\begin{abstract}
Viral hemorrhagic septicemia virus (VHSV) was isolated from populations of Pacific sardine Sardinops sagax from the coastal waters of Vancouver Island, British Columbia, Canada, and central and southern California, USA. The virus was also isolated from Pacific mackerel Scomber japonicus in southern California, from eulachon or smelt Thaleichthys pacificus, and surf smelt Hypomesus pretiosus pretiosus from Oregon, USA. Mortality and skin lesions typical of viral hemorrhagic septicemia in other marine fish species were observed among sardine in Canada and in a few surf smelt from Oregon, but the remaining isolates of VHSV were obtained from healthy appearing fish. The prevalence of VHSV among groups of apparently healthy sardine, mackerel and smelt ranged from 4 to $8 \%$ in California and Oregon. A greater prevalence of infection (58\%) occurred in groups of sardine sampled in Canada that sustained a naturally occurring epidemic during 1998-99. A captive group of surf smelt in Oregon exhibited an $81 \%$ prevalence of infection with clinical signs in only a few fish. The new isolates were confirmed as North American VHSV and were closely related based on comparisons of the partial nucleotide sequence of the glycoprotein (G) gene. The VHSV isolates from sardine in Canada and California were the most closely related, differing from isolates obtained from other marine fish species and salmonids in British Columbia, Canada, Alaska and Washington, USA. These new virus isolations extend both the known hosts (sardine, mackerel and 2 species of smelt) and geographic range (Oregon and California, USA) of VHSV.
\end{abstract}

KEY WORDS: Pilchard $\cdot$ Sardine $\cdot \mathrm{VHSV} \cdot \mathrm{G}$-gene $\cdot$ Glycoprotein $\cdot$ Rhabdovirus Resale or republication not permitted without written consent of the publisher

\section{INTRODUCTION}

During the past $10 \mathrm{yr}$ there has been an increased awareness that viral hemorrhagic septicemia virus (VHSV) is present in many marine fish populations of the North Pacific and North Atlantic Oceans, mainly the North and Baltic Seas (Meyers \& Winton 1995, Stone et al. 1997, Mortensen et al. 1999, Smail 1999, Takano et al. 2001, Dopazo et al. 2002, Winton \& EinerJensen 2002). The interest in marine reservoirs for VHSV in North America began in 1988 with the first observations of the virus among returning adult salmon in the Pacific Northwest (Winton et al. 1991). Studies to trace the potential origin of the virus led to detections of VHSV in several marine fish populations that initially included Pacific herring Clupea pallasi and Pacific cod Gadus macrocephalus (Meyers et al. $1992,1994)$. The virus was later detected as the cause of mass mortality among populations of Pacific herring, Pacific hake Merluccius productus and walleye pollock Theragra chalcogramma in Alaska (Meyers et al. 1999). VHSV was also recovered from normal- 
appearing shiner perch Cymatogaster aggregata, Pacific herring, and 3-spine sticklebacks Gasterosteus aculeatus in British Columbia, Canada (Kent al. 1998). Surveys of coastal waters of the state of Washington revealed the presence of VHSV in Pacific herring and sand lances Ammodytes hexapterus, but not among 11 other marine fish species captured in Puget Sound (Amos et al. 1998, Kocan et al. 2001a). Despite the ease of detecting VHSV in a broad range of marine fish hosts, the overall impact of the virus on these fish populations has been difficult to assess. That VHSV may have significant negative impacts is suggested by field studies of Pacific herring abundance in Alaska (Marty et al. 1998) and the recent epidemiological studies of Pacific herring and sand lances in Puget Sound, Washington (Kocan et al. 1997, 2001a), and in Alaska (Hershberger et al. 1999). These studies correlated the size and age structure of marine fish populations to the prevalence and severity of diseases, including that caused by VHSV infection under field and controlled laboratory conditions. They suggest that under the appropriate conditions the virus can cause significant disease associated with morbidity and mortality in populations of marine fish. Similar studies of other pelagic marine fishes are needed because they are the basis of important sport and commercial fisheries and significant numbers are often moved in international trade.

The Pacific sardine Sardinops sagax is a clupeid inhabiting the warmer coastal waters of many ocean basins (Wolf et al. 2001). In the Pacific regions of North America, sardine (also referred to as pilchards) are part of an active commercial fishery extending from Mexico to British Columbia, Canada (Wolf et al. 2001). The principal spawning activity occurs among the more southern populations of sardine (including California, USA), with older fish undergoing extensive migrations to the north for feeding and later returning to the south to spawn. Sardine may live for up to $13 \mathrm{yr}$ and generally enter the fishery at $3 \mathrm{yr}$ of age or more. Population abundance expands and contracts, sometimes radically with fishing pressure, feed abundance and environmental changes (Wolf et al. 2001). Sardine tolerate temperature ranges from 10 to $26^{\circ} \mathrm{C}$ with optimal spawning at 14 to $16^{\circ} \mathrm{C}$ (Wolf et al. 2001). Sardine are primarily used for bait and fresh or frozen fish food. Significant numbers of frozen sardine are shipped to south Australia to feed captive southern bluefin tuna Thunnus maccoyii, an industry that requires approximately 55000 t of wet feed weight per year.

The Pacific mackerel Scomber japonicus is a scombrid that was once an important pelagic species of the California fishery before serious declines began in the 1930s (Konno et al. 2001). Mackerel are found at water temperatures ranging from 10 to $22^{\circ} \mathrm{C}$ (Konno et al. 2001). Currently, mackerel represent a smaller compo- nent (23 $205 \mathrm{t}$ ) of the California fishery compared to $59925 \mathrm{t}$ of sardine. Mackerel are consumed by humans as fresh fish or used as bait or pet food.

Sablefish Anoplopoma fimbria, also known as blackcod, is an important commercial species that is fished along the coast of North America. In British Columbia, over 4000 t were landed in 1997 (Stocker 2001). In the Pacific region of North America the species ranges from Alaska to Baja California, Mexico. Sablefish spawn from January to March in deep water along the continental shelf. Juveniles migrate inshore and spend from 2 to 5 yr near the shore when they move offshore into the fishery (Hart 1973).

The eulachon Thaleichthys pacificus is an anadromous fish belonging to the family Osmeridae (smelt), with a geographic range from central California to Alaska (Sweetnam et al. 2001). After spending up to 5 yr living on the outer continental shelf of the Pacific Ocean and at a size approaching $30 \mathrm{~cm}$, eulachon migrate to the lower reaches of coastal rivers to spawn (Sweetnam et al. 2001). Populations of these fish, once found abundantly each year, have been infrequently observed since 1988 and traditional seasonal returns of eulachon to the Columbia River, Oregon, have been relatively poor in recent years. The temperatures during their freshwater migration and spawning may range from 1 to $12^{\circ} \mathrm{C}$. Surf smelt, also known as silver smelt Hypomesus pretiosus pretiosus, is a pelagic species utilizing the nearshore marine environment to spawn. This species occurs from Alaska to central California and may be split into distinct subpopulations according to their spawning time: summer, fall-winter, and year around. Temperatures at which spawning occurs are above $10^{\circ} \mathrm{C}$ (Schaefer 1936).

These marine and anadromous fish from Pacific North America represent a small number of the species for which investigations of pathogens, particularly VHSV, have been started to provide information addressing both fisheries management and international trade concerns. Our initial studies of these fish species indicate that each can be a reservoir for VHSV and that under certain circumstances, populations of sardine and perhaps other species can undergo mass mortality episodes.

\section{MATERIALS AND METHODS}

Fish. Fish were collected and transported, on ice or frozen, to each of the 3 respective laboratories in British Columbia, Canada, Oregon or California, USA. The fish were captured by fishermen or research scientists and were generally processed on the same or the day following collection. Two samples of sardine 
submitted to the Fish Health Laboratory at the University of California Davis were received frozen from inventory at a packing plant. The single shiner perch and the sardine and herring collected from British Columbia in 2002 were frozen and stored at $-20^{\circ} \mathrm{C}$ before transport to the laboratory. Information regarding the species, date and location caught, and surface water temperatures for the samples collected in this study are listed in Table 1.

Virus isolation. The procedures used for detection of VHSV or any other viral agents that might have been present in these fish were consistent with those found in the American Fisheries Society Fish Health Section Bluebook (Thoesen 1994) or the OIE Manual for Aquatic Animal Diseases (OIE 2000). Samples were analyzed separately or as 5 -fish pools (Table 1). Portions of the gill and/or kidney and spleen were prepared as homogenates that were inoculated onto the CHSE-214 (Lannan et al. 1984) or the EPC (Fijan et al. 1983) cell lines with or without polyethylene glycol (PEG) pretreatment as described by Batts \& Winton (1989). Inoculated cells were incubated at $15^{\circ} \mathrm{C}$ for 14 to $21 \mathrm{~d}$. Virus concentrations in selected fish tissues were determined by plaque assays on EPC cells under the same conditions (Batts \& Winton
1989). Autolyzed tissues from dead sablefish were tested for the presence of VHSV using PCR and VHSV-specific primers (Einer-Jensen et al. 1995).

Virus identification and G-gene sequencing. The nucleotide sequence of the G-gene has been demonstrated as useful for both identification and distinguishing strains of VHSV (Jørgensen et al. 1995, Benmansour et al. 1997, Stone et al. 1997). The new isolates of VHSV were compared to 3 reference strains of VHSV isolated from rainbow trout Oncorhynchus mykiss from France (FR-rt-71 or 07-71), Atlantic cod Gadus morhua from Denmark (DEN-c-79 or Cod ulcus 79) (Jensen et al. 1979), and turbot Scophthalmus maximus from Scotland (SCT-t-95) (Ross et al. 1994). Reverse transcription and nested polymerase chain reaction of the central region of the G-gene of the VHSV isolates was performed following the procedures outlined in Huang et al. (1996). The first round of 30 PCR cycles amplified a 914-bp region with primers 5 '-ACTACCTACACAGAGTGAC-3' (330 to 348 nucleotides [nt] of Makah VHSV G-gene, GenBank submission U28747.1) and 5'-CAATTTGTCCCCGAATATCAT-3' (1243 to $1223 \mathrm{nt}$ ). The second round was nested within the first with 30 cycles of amplification yielding a 758bp product with primers 5'-TCCCGTCAAGAGGC-

Table 1. Fish examined for presence of viral hemorrhagic septicemia virus (VHSV) from sites in British Columbia, Canada, and Oregon and California, USA, and the corresponding coastal or river water temperatures at the time of collection

\begin{tabular}{|c|c|c|c|c|}
\hline Species & $\begin{array}{l}\text { No. } \\
\text { of fish }\end{array}$ & $\begin{array}{c}\text { Date } \\
(\mathrm{mm} / \mathrm{yy})\end{array}$ & Location (water temp.) & $\begin{array}{l}\text { Virus isolate } \\
\text { and designation }\end{array}$ \\
\hline \multicolumn{5}{|c|}{ British Columbia } \\
\hline Sardine & 163 & $12 / 98-02 / 99$ & Queen Charlotte Straits $\left(8-9^{\circ} \mathrm{C}\right)$ & BC-s-99 \\
\hline Herring & 37 & $12 / 98-02 / 99$ & Queen Charlotte Straits $\left(8-9^{\circ} \mathrm{C}\right)$ & BC-h-99 \\
\hline Sablefish & 3 & $12 / 98-02 / 99$ & Queen Charlotte Straits $\left(8-9^{\circ} \mathrm{C}\right)$ & Virus by PCR only \\
\hline Ratfish & 2 & $01 / 99$ & Queen Charlotte Straits $\left(8-9^{\circ} \mathrm{C}\right)$ & No virus \\
\hline Sardine $^{a}$ & 43 & $02 / 02-03 / 02$ & NW Vancouver Island $\left(7-8^{\circ} \mathrm{C}\right)$ & BC-s-02 \\
\hline Herring $^{\mathrm{a}}$ & 37 & 02/02-03/02 & NW Vancouver Island $\left(7-8^{\circ} \mathrm{C}\right)$ & BC-h-02 \\
\hline Shiner perch ${ }^{\mathrm{a}}$ & 1 & $03 / 02-03 / 02$ & NW Vancouver Island $\left(7-8^{\circ} \mathrm{C}\right)$ & BC-sp-02 \\
\hline \multicolumn{5}{|l|}{ Oregon } \\
\hline Eulachon & $80^{\mathrm{b}}$ & 03/01 & Sandy River $\left(7^{\circ} \mathrm{C}\right)$ & O-e-01 \\
\hline Surf smelt & 85 & 05/01 & Winchester Bay $\left(11^{\circ} \mathrm{C}\right)$ & O-ss-01 \\
\hline Sardine & 100 & $08 / 02$ & Astoria $\left(19.4^{\circ} \mathrm{C}\right)$ & No virus \\
\hline \multicolumn{5}{|l|}{ California } \\
\hline Sardine & $25^{\mathrm{b}}$ & $02 / 01$ & Los Angeles $\left(14.4^{\circ} \mathrm{C}\right)$ & C-s-01 \\
\hline Mackerel & $25^{\mathrm{b}}$ & $04 / 01$ & Santa Catalina $\left(13.3^{\circ} \mathrm{C}\right)$ & C-m-01 \\
\hline Sardine & $25^{\mathrm{b}}$ & 05/01 & Salinas $\left(12.8^{\circ} \mathrm{C}\right)$ & No virus \\
\hline Sardine $^{a}$ & $25^{\mathrm{b}}$ & 08/01 & Huntington Beach $\left(20.0^{\circ} \mathrm{C}\right)$ & No virus \\
\hline Sardine $^{a}$ & $25^{\mathrm{b}}$ & $12 / 01$ & Monterey Bay $\left(12.8^{\circ} \mathrm{C}\right)$ & No virus \\
\hline Sardine & $30^{\mathrm{b}}$ & 03/02 & Malibu $\left(15.6^{\circ} \mathrm{C}\right)$ & CMA-s-02 \\
\hline Sardine & $30^{\mathrm{b}}$ & 03/02 & Moss Landing $\left(12.2^{\circ} \mathrm{C}\right)$ & CML-s-02 \\
\hline Sardine & 100 & 08/02 & Monterey $\left(13.9^{\circ} \mathrm{C}\right)$ & No virus \\
\hline Sardine & 100 & 08/02 & Los Angeles $\left(19.4^{\circ} \mathrm{C}\right)$ & No virus \\
\hline
\end{tabular}


CAC-3' (422 to $438 \mathrm{nt}$ ) and 5'-TTCCAGGTGTTGTTTACCG-3' (1179 to $1161 \mathrm{nt}$ ). Each of the PCR products were purified with a StrataPrep PCR purification kit (Stratagene) and sequenced by combining, in 4 individual reactions, the second-round primers and 2 internal primers, 5'-ACAATGGCATGCACGGTGACA-3' (776 to $796 \mathrm{nt}$ ) and 5'-TGCCATTGTGAGCCCCCA3'(784 to $767 \mathrm{nt})$, and labeled with a fluorescent dye terminator cycle sequencing kit (Applied Biosystems). All reactions were analyzed on an ABI 310 Genetic Analyzer (Applied Biosystems). Sequences were trimmed to $669 \mathrm{nt}$ with a MacVector Program, and pairs of virus sequences were analyzed with the ClustalW alignment program to observe mismatched nucleotides.

\section{RESULTS}

\section{Virus isolations}

Virus isolates were obtained from sardine, mackerel, herring, eulachon, shiner perch, and surf smelt (Table 1, Fig. 1). VHSV was detected in sablefish by PCR only. The geographic range of the isolates obtained extended from the northern coast of Vancouver Island, British Columbia, to the Gulf of Catalina in southern California (Fig. 1). In isolating the viruses cytopathic effects were generally more prominent on the EPC compared to the CHSE-214 cell line, a situation encountered in all 3 laboratories. Viruses were isolated using cell monolayers with or without pretreat-

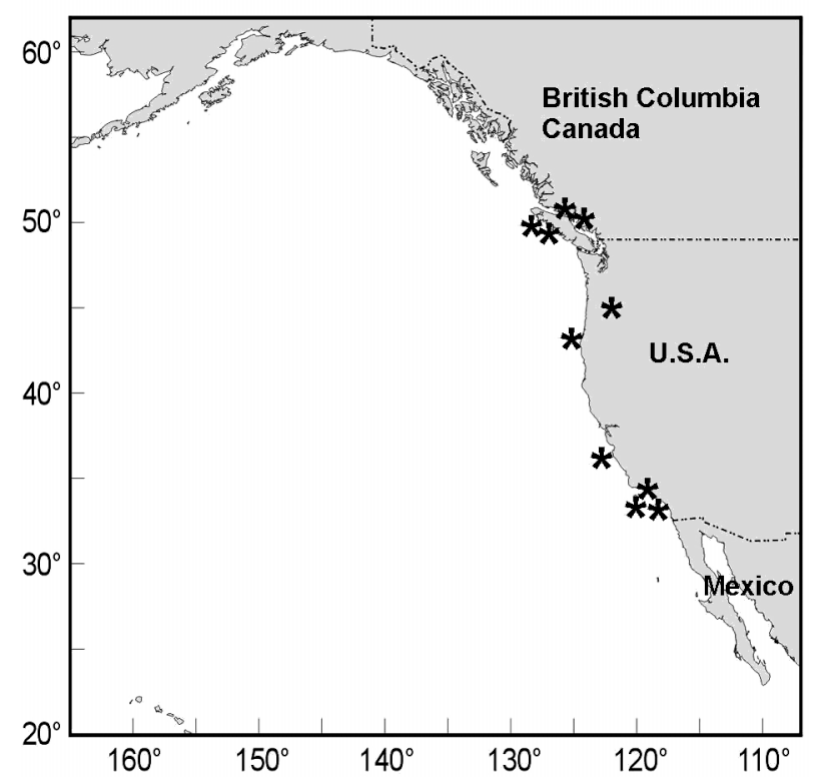

Fig. 1. Locations $(*)$ where viral hemorrhagic septicemia virus (VHSV) was detected in marine or anadromous fish from or near the coastal waters of North America ments of PEG. Information relevant to virus isolations from each of the 3 geographical regions examined is provided below. No other viruses were isolated during the course of the study.

\section{British Columbia}

Fish were examined from 2 mass mortality episodes. The first occurred between November 1998 and February 1999 in the Queen Charlotte Strait. The second epidemic in December 2001 to March 2002 occurred in Kyuquot Sound and Nootka Sound on the NW coast of Vancouver Island and in Spiller Channel located in Queen Charlotte Sound. In both episodes the mortality predominantly involved sardine, although deaths among other fish species were reported. External signs observed on some, but not all, moribund and dead sardine were similar to those described in Pacific herring with viral hemorrhagic septicemia (Meyers et al. 1994). Other fish species examined included sablefish, herring, ratfish Hydrolagus colliei and shiner perch. Clinical signs consistent with VHSV were found among herring and some sardine, but not the other fish examined. Virus was isolated from 95 of 163 sardine and 26 of 37 herring examined in the first episode. Virus concentrations ranged from $1.4 \quad 10^{2}$ to $1.6 \quad 10^{6} \mathrm{pfu} \mathrm{g}^{-1}$ in pooled kidney and spleen tissue from moribund sardine and herring. Virus was detected in 1 of 3 sablefish by the PCR, but not isolated by cell culture. Virus was not detected in ratfish or shiner perch. Samples examined from the second mass mortality episode were collected near the end of the epidemic in March 2002. Because of the remote locations, fish were frozen $\left(-20^{\circ} \mathrm{C}\right)$ for storage until laboratory testing could be conducted. VHSV was recovered from 6 of 43 sardine, 2 of 37 herring and 1 of 1 shiner perch.

\section{Oregon}

Eulachon were collected from the Sandy River during their spawning migration in March 2001. All fish were healthy in appearance. Of the 80 fish examined, 9 were mature females. Virus isolates were obtained from 6 of the 15 pooled tissue samples (each pool with 5 fish) inoculated onto the EPC line. In May 2001, surf smelt obtained from a live bait supplier in Winchester Bay on the southern Oregon coast were transferred to aquaria at the Marine Science Center, Newport, Oregon. Atypical mortality began within days with a few fish exhibiting focal areas of epidermal ulceration and hemorrhaging, and mechanical skin abrasions in the oral/nasal regions. VHSV was 
isolated from 60 of 60 dead or moribund individuals, and from 3 of 17 healthy appearing fish. Virus concentrations ranged from $4.2 \quad 10^{4}$ to $1.2 \quad 10^{6} \mathrm{pfu} \mathrm{g}^{-1}$ of tissue. Subsequent sampling of the surviving fish 4 wk later resulted in virus isolation from 3 of 8 apparently healthy individuals.

\section{California}

All sardine and mackerel examined from California coastal waters were healthy in appearance. The fish ranged in fork length from 13.0 to $24.5 \mathrm{~cm}$, with most populations having a median length of approximately $17.0 \mathrm{~cm}$. Viruses were isolated from sardine collected at 3 southern California locations (Los Angeles, Santa Catalina, Malibu), with surface water temperatures ranging from 13.3 to $15.6^{\circ} \mathrm{C}$ (Table 1 ). No virus was detected in one group (Salinas) from central California in 2001, but virus was found in a second group in this region from Moss Landing in 2002. Water temperatures at these 2 central California locations ranged from 12.2 to $12.8^{\circ} \mathrm{C}$. The 2 groups of fish received frozen yielded no virus (Huntington Beach in southern California and Monterey Bay in central California). No virus was detected among recent groups of sardine from 2 California locations and 1 location in Oregon that were all collected on the same date and where water temperatures ranged from 13.9 to $19.4^{\circ} \mathrm{C}$. The prevalence of VHSV in groups of sardine and mackerel sampled in California was estimated to be from 4 to $8 \%$. This prevalence was based on the assumption that 1 fish in 1 or 2 of the pooled samples that contained 5 fish tissues each was infected with VHSV. Due to the low prevalence of infection, concentrations of virus in fish tissues were not evaluated.

\section{G-gene sequences of virus isolates}

A 669 nt sequence of the $G$ gene obtained from the new isolates demonstrated that they were VHSV and all closely related (Table 2). These new isolates grouped with previously described Pacific North American marine isolates from salmon, herring, and cod with $10 \mathrm{nt}$ or less differences in this $669 \mathrm{nt}$ region. With the exception of the isolate (O-e-01) from eulachon in the Sandy River, Oregon, the remaining new isolates differed by less than 3 nt suggesting they could represent a closely related subgroup of Pacific North American marine VHSV. Despite a wide geographic range, the isolates from sardine in California and British Columbia were either identical in 2002 or differed by 1 to 2 nt from

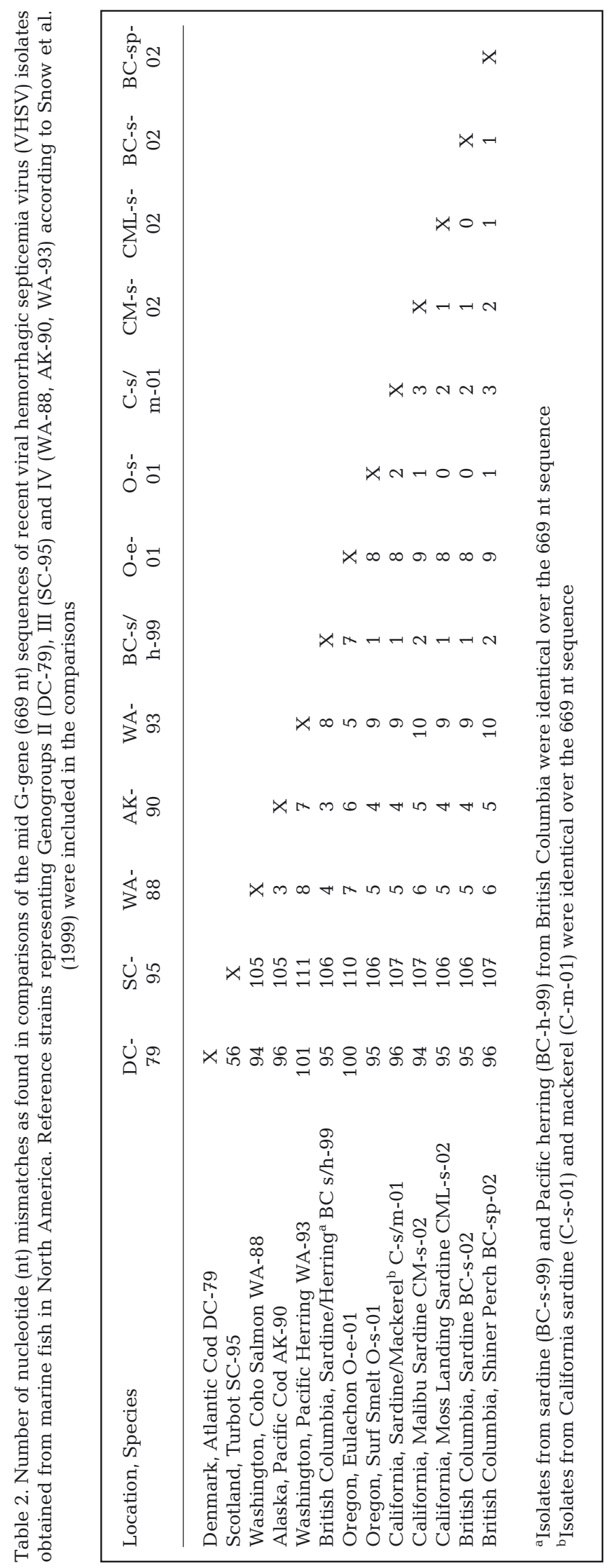


isolates obtained from the same regions in 2001. In contrast, isolates of VHSV from marine fish or salmon in Alaska, British Columbia, or Washington were more similar to each other than to the sardine isolates, with the exception of the new isolates from herring in 1999 and shiner perch in 2002 obtained from fish collected at the same time and location as the dying sardine in British Columbia.

\section{DISCUSSION}

In this study, the North American strain of VHSV was isolated from 4 new hosts (sardine, mackerel, eulachon and surf smelt) and detected by PCR from 1 additional host (sablefish). In addition, the geographic range of VHSV was extended to include the states of Oregon and California. On at least 2 occasions in British Columbia, VHSV was associated with mass mortality among sardine, but in most cases the virus isolates were obtained from healthy appearing fish. The new VHSV isolates belonged to the group of North American VHSV that has a low virulence for salmonid fishes, unlike the freshwater strains from Europe (Winton et al. 1991).

\section{Host and geographic range}

VHSV has been isolated from many marine and anadromous fish populations and is established in certain freshwater fishes including salmonids (Winton \& Einer-Jensen 2002). The broad host range demonstrated for VHSV in the marine environment has led to the suggestion that perhaps all marine fish are susceptible to infection (Stone et al. 1997). Marine isolates of VHSV range from high to very low virulence for marine fish and are generally of low virulence for salmonids (Meyers et al. 1992, 1994, 1999, Meier et al. 1994, Meyers \& Winton 1995, Dixon et al. 1997, Kocan et al. 1997, Kent et al. 1998, Dixon 1999, Mortensen et al. 1999, Smail 1999, King et al. 2001, Takano et al. 2001). To date, isolates of VHSV have only been obtained from marine fish in the North Pacific and North Atlantic Oceans, despite the large movements of frozen bait fish from these regions to the southern hemisphere, and in particular, the southern blue fin tuna aquaculture in South Australia. It is presumed that VHSV originated among fish in the northern Pacific or Atlantic oceans and only more recently became established in freshwater salmonids in continental Europe, most likely when feeding of marine fish was a typical practice in the early days of rainbow trout farming (Meyers \& Winton 1995, Stone et al. 1997, Dixon 1999).

\section{Relationships of isolates}

Recent studies comparing the glycoprotein and nucleoprotein gene sequences of numerous VHSV isolates generally suggest separation into groups based upon their geographic origin (Benmansour et al. 1997, Stone et al. 1997, Snow et al. 1999). The principal genogroups/genotypes correspond to VHSV isolates from freshwater fish in continental Europe (Type I), marine fish from the North Sea in Europe (Type II), and isolates from marine fish in the Pacific Ocean of North America (Type III). A 4th genogroup/type was suggested by Snow et al. (1999), who found isolates from the Baltic Sea differing from the freshwater or North Sea isolates. The new VHSV isolates from sardine, mackerel, herring, eulachon and shiner perch indicated they group closely with the North American genogroup (Type III) having no more than $10 \mathrm{nt}$ mismatches out of $669(1.5 \%)$ as the greatest difference from other members within this group (Table 2). The difference of 3 nt or less among 9 of the 10 new isolates suggests a subgroup that is more homogeneous than the previously known North American strains of VHSV found in Washington, Alaska, and British Columbia. All new isolates from California fell into this putative new subgroup that may be the more common type of VHSV in the most southerly range of the virus. The identical G-gene sequences found for the 3 new isolates from Oregon surf smelt (O-ss-01) and sardine from British Columbia (BC-s-02) and California (CAML-s-02) suggest that the virus can move with highly migratory fish from the southern region to northern areas. Although more isolates need to be examined, the viruses from the more southern range were most different from those known from numerous fish species in the more northern range (e.g. British Columbia, Washington, and Alaska) with 2 exceptions. These were the isolates collected in British Columbia from herring (BC-h-99) and shiner perch (BC-sp-02) during the mass mortality of sardine. In both cases, the dying sardine were viewed as the source of the virus infections in herring and shiner perch.

A comparison of the new VHSV isolates showed they differed substantially from members of European Genogroups I and II, by a minimum of 94 nt mismatches (Table 2). The presence of a member of Genogroup II in the North Pacific has recently been reported from wild Japanese flounder Paralichthys olivaceus in Japan (Takano et al. 2001). Nishizawa et al. (2002) compared the partial G- and P-gene sequences of 8 isolates of VHSV from Japanese flounder to isolates of VHSV representing the other genotypes/ groups. They found 2 genotypes among the 8 isolates from Japan, with 7 isolates grouping in the North American Genogroup III and a single isolate grouping 
in the North Sea Genogroup II. This suggests that mixing of genogroups/types in the western regions of the North Pacific Ocean has occurred, a situation not yet encountered in the eastern Pacific Ocean off the coast of North America.

\section{Potential impacts}

Episodes of mortality associated with VHSV infections of marine fish in North America have been recorded most dramatically among Pacific herring, Pacific hake and walleye pollock in Alaska (Meyers et al. 1994, 1999), and more recently among sardine in British Columbia. In these episodes, thousands of dead fish were observed over periods ranging from 4 to 8 wk, with total biomass presumed to be in the thousands of tons. Potentially as important are the unknown impacts of VHSV infections on early life stages or during subclinical or chronic infections of older fish. The long-term studies of Pacific herring populations by Marty et al. (1998) in Alaska indicate that VHSV is associated with chronic lesions, including mineralization of the myocardium, hepatocellular necrosis, submucosal gastritis, meningoencephalitis, and skin ulcerations. Impairments of several organ systems from lesions induced by VHSV would be expected to contribute to compromised functioning and survival of infected fish. These impairments, when combined with other stressors including periods of subtle to dramatic environmental change, may induce increased or epidemic mortality. In the mass mortality episodes with sardine in 1998-99 and in 2001-02, we presume that fish migrated further north with warm water events, suddenly encountered colder water near the limits of their tolerance $\left(8\right.$ to $\left.9^{\circ} \mathrm{C}\right)$, and then succumbed to VHSV and other causes of death.

\section{Effects of temperature}

The new isolates of VHSV were obtained from fish in water temperatures ranging from 7 to $15.6^{\circ} \mathrm{C}$, the lower temperature being below that tolerated by sardine and mackerel. Sardine prefer warmer waters of 20 to $24^{\circ} \mathrm{C}$ occurring in the coastal regions of southern California and Baja California, Mexico. At these higher temperatures we assume that replication of VHSV is restricted and could not be carried by migrating fish to more southern locations, either in the Pacific or Atlantic Oceans. The effect of water temperature on the progress of VHSV infections has been investigated in a few experimental trials. Castric \& de Kinkelin (1984) found that European seabass Dicentrarchus labrax and turbot showed neither mortality nor mor- bidity after intraperitoneal injections or bath exposures to Genogroup I isolates (freshwater strains) of VHSV at $20^{\circ} \mathrm{C}$. In contrast, $100 \%$ of the virus-exposed fish died at seawater temperatures of 12 to $14^{\circ} \mathrm{C}$. Subsequent trials demonstrated that a total of $50 \%$ (5 of 10) of the turbot injected with VHSV died at a seawater temperature of $18^{\circ} \mathrm{C}$. These results were consistent with field observations of VHSV epidemics in rainbow trout that generally occurred at freshwater temperatures below $14^{\circ} \mathrm{C}$ (Castric \& de Kinkelin 1980). Although Castric \& de Kinkelin (1984) used Genogroup I VHSV, their results suggest an upper temperature threshold for in vivo infections in marine fish between 18 and $20^{\circ} \mathrm{C}$. In general, seawater temperatures range from 4 to $16^{\circ} \mathrm{C}$ in areas of the Pacific Ocean where most VHSV isolates have been obtained from marine fish. In Japan, VHSV was isolated from wild flounder collected from multiple sites in the archipelago over a water temperature range of 7 to $18^{\circ} \mathrm{C}$ (Takano et al. 2001). In the Pacific Ocean off the coast of North America, naturally occurring epidemics of VHSV in marine fish have been reported in Pacific herring, Pacific hake, and walleye pollock in Alaska when ambient water temperatures were approximately 4 to $5^{\circ} \mathrm{C}$ (Meyers et al. 1994, 1999, T. Meyers pers. comm.). The optimum temperature for VHSV infections in Pacific herring based on laboratory trials and field observations in Washington is 8 to $10^{\circ} \mathrm{C}$ (R. Kocan pers. comm.). Whether distinct temperature tolerances exist between isolates of VHSV from the more northern compared to the southern range of the virus must be examined. It is possible that isolates obtained from fish in the more southern range of the virus have acquired a higher upper temperature tolerance, a phenotypic property that was demonstrated for Genogroup I VHSV by de Kinkelin et al. (1980). They found that serial passages of VHSV in cell cultures at increasing temperatures from 14 to $25^{\circ} \mathrm{C}$ resulted in a temperature-resistant variant able to replicate efficiently at $25^{\circ} \mathrm{C}$. The $25^{\circ} \mathrm{C}$-tolerant virus was less pathogenic to rainbow trout when tested at water temperatures of 8 to $12^{\circ} \mathrm{C}$. They concluded that VHSV can be adapted to replicate at higher temperatures in cell cultures, and that the variant obtained may have reduced translation of certain viral proteins (L and G) and a reduced virulence for rainbow trout. Experimental studies that compare the in vitro and in vivo temperature tolerances and virulence may show significant differences between North American strains of VHSV from the northern and southern range of the virus. Of particular importance would be the upper limit of water temperature at which VHSV replicates in marine fish species having a large migratory range.

Risk evaluations of VHSV moving with migratory fish or dead fish products have identified water temperature and the effects of temperature on the stability 
of the virus as important concerns (Anon 2002). If an upper threshold for virus infection were known, fish caught during these seawater temperature periods would represent a reduced risk for harboring the virus. Water temperatures of 17 to $18^{\circ} \mathrm{C}$ probably represent the upper limit of the range where the North American strain of VHSV might cause significant harm to infected fish, based on data from freshwater strains of VHSV and the absence of controlled laboratory trials with the marine fish species of concern. This potential temperature threshold may explain, in part, why no virus was detected in 2 samples of sardine collected at water temperatures of 19.4 to $20^{\circ} \mathrm{C}$ in our study (Table 1). Data on the stability of marine VHSV isolates to freeze-thaw cycles, or after release from frozen fish placed into seawater, are also critical to risk assessments of the potential for spread of the virus with bait fish.

Evidence of partial freezing inactivation of virus was demonstrated by Meyers et al. (1999) in frozen wildcaught Pacific hake and herring from Alaskan waters. Meyers et al. (1999) suggested that up to a 1000-fold reduction in infectivity occurred with a single round of freezing at $-80^{\circ} \mathrm{C}$, and thawing thus impairs initial isolation of the virus that often requires blind passages. Mortensen et al. (1999) suggested a similar reduction of virus infectivity might occur upon thawing of frozen fish. If concentrations of virus in the fish tissues are sufficiently high, detectable virus may survive a freeze-thaw cycle (Meyers et al. 1994). We presume that if initial virus concentrations of VHSV in fish tissues are low, as found in healthy appearing fish, then freezing might effectively eliminate detectable virus. If tissue concentrations are $10^{7} \mathrm{pfu}^{-1}$ or higher, as found in dead and dying Pacific herring (Kocan et al. 1997, 2001a), then freezing may reduce but not eliminate detectable virus. Two groups of sardine in California from which VHSV was not detected were frozen fish samples (Table 1). The lower prevalence of VHSV recovered from fish in British Columbia in 2002, compared with levels recovered during 1998, was also a likely result of most samples being frozen after collection in the field. Isolates of VHSV (F1 Genogroup I) were found to be more stable to repeated freeze thaws in media containing serum (de Kinkelin \& Scherrer 1970).

The potential fate of virus after release into seawater was examined for marine isolates of VHSV by Parry \& Dixon (1979). They found that marine isolates from Europe and North America had similar survival at each of the 4 temperatures examined $\left(4,10,15\right.$, and $\left.20^{\circ} \mathrm{C}\right)$. Stability, as measured by virus infectivity for cell cultures, was inversely correlated with temperature, with maximum survival at $4{ }^{\circ} \mathrm{C}$ ranging from 7 to $21 \mathrm{~d}$, while at 15 to $20^{\circ} \mathrm{C}$ the North American strains survived for less than 7 d. Kocan et al. (2001b) demonstrated even more rapid inactivation of VHSV from Pacific herring held in seawater. At a seawater temperature of $15^{\circ} \mathrm{C}$, the virus lost $50 \%$ of its infectivity within $10 \mathrm{~h}$, and none could be detected after $40 \mathrm{~h}$, suggesting the virus has a limited capacity to survive once released from the host.

\section{Conclusions}

Naturally occurring epidemics due to VHSV in marine fish most likely result from several environmental, nutritional and other stressors that predispose a large naïve population to infection from carrier fish (Marty et al. 1998, Hershberger et al. 1999). The spread of the virus either rapidly or slowly through the population may result in either mass mortality or a slow chronic course of infection (Kocan et al. 2001a). The low subclinical carrier rate of the virus in sardine populations in California may explain why VHSV in our study was often found at a low prevalence $(<8 \%)$ and in the absence of disease signs. When other significant stressors are present, such as the low water temperatures experienced by sardine in the coastal waters of Vancouver Island, British Columbia, episodes of mass mortality may occur. The geographic location where sardine are initially exposed to VHSV is unknown. Sardine migrating to the north may carry a virus obtained from more southern waters, although the converse (infections obtained in the north) cannot be completely excluded. Sampling of younger fish in their waters of origin would resolve this question. All new VHSV isolates we describe had similar G-gene sequences and differed from many other marine and anadromous VHSV isolates detected from the northern range of the virus (Washington and Alaska and British Columbia). Also, the identical G-gene sequences of VHSV isolates from sardine in California and British Columbia suggest that sardine are carrying the virus from a more southern area that is transmitted to local fish such as shiner perch and Pacific herring. These species would otherwise carry strains of VHSV more similar to isolates from the local region. This possibility would be consistent with our general knowledge that marine VHSV isolates tend to group more by geographic region than by host species (Benmansour et al. 1997, Stone et al. 1997, 1999, Nishizawa et al. 2002).

The presence of VHSV in sardine and mackerel in California may represent the most southern distribution expected for the virus, since water temperatures increase significantly further south. This temperature barrier, combined with a site of origin in the northern hemisphere, may explain the current geographic range of a virus viewed to be capable of infecting all 
species of marine fish (Stone et al. 1997). The observation of VHSV in sardine and mackerel stimulates many questions relevant to these and other large pelagic fisheries: (1) What is the temporal and spatial distribution and host range of VHSV in these fish, particularly in more southerly latitudes? (2) What are the potential impacts of the virus on these populations? (3) Is the prevalence of virus an indicator of the overall health of these populations? (4) What stressor(s) induce outbreaks, and were previously unexplained mortality episodes in sardine potentially related to VHSV infections, or were they due to other factors as shown in Australia (Hyatt et al. 1997, Whittington et al. 1997)? (5) What are the risks associated with the capture, freezing, transport and feeding of these infected fish to other marine fish in distant geographic locations? Answers to these questions will be obtained by combining comprehensive fish health field surveys and controlled laboratory trials with studies of other important factors known to influence the population dynamics of these pelagic fish species.

Acknowledgements. We wish to thank Ms. Terry McDowell and Dr. William Cox for their assistance. This work was supported in part by the National Sea Grant College Program of the US Department of Commerce's National Oceanic and Atmospheric Administration under NOAA Grant NA06RG0142, project RA Moll/UC-SG, through the California Sea Grant College Program; and in part by the California Resource Agency. The views expressed herein do not necessarily reflect the view of any of those organizations. The Oregon Department of Fish and Wildlife and the Department of Fisheries and Oceans, Canada, also supported parts of this work. We also thank Mr. Steve Seltzer, Mrs. Diane-Pleschner Steele, and individual fish processors that contributed to this work.

\section{LITERATURE CITED}

Amos K, Thomas J, Hopper K (1998) A case history of adaptive management strategies for viral hemorrhagic septicemia virus (VHSV) in Washington state. J Aquat Anim Health 10:152-159

Anonymous (2002) Animal quarantine policy memorandum 2002/14, interim biosecurity measures for pilchards and mackerel. Dept of Agriculture, Fish \& Forestry Australia, Canberra

Batts WN, Winton JR (1989) Enhanced detection of infectious hematopoietic necrosis virus and other fish viruses by pretreatment of the cell monolayers with polyethylene glycol. J Aquat Anim Health 1:284-290

Benmansour A, Basurco B, Monnier AF, Vende P, Winton JR, de Kinkelin P (1997) Sequence variation of the glycoprotein gene identifies three distinct lineages within field isolates of viral haemorrhagic septicaemia virus, a fish rhabdovirus. J Gen Virol 78:2837-2846

Castric J, de Kinkelin P (1980) Occurrence of viral haemorrhagic septicemia in rainbow trout Salmo gairdneri Richardson. J Fish Dis 3:21-27

Castric J, de Kinkelin P (1984) Experimental study of the sus- ceptibility of two marine fish species, sea bass (Dicentrarchus labrax) and turbot (Scophthalmus maximus), to viral haemorrhagic septicaemia. Aquaculture 41:203-212

de Kinkelin P, Scherrer (1970) Le virus d'Egtved. I. Stabilité, développment et structure du virus de la souche danoise F1. Ann Rech Vét 1:17-30

de Kinkelin P, Bearzotti-Le Berre M, Bernard J (1980) Viral hemorrhagic septicemia of rainbow trout: selection of a thermoresistant virus variant and comparison of polypeptide synthesis with the wild-type virus strain. J Virol 36: 652-658

Dixon PF (1999) VHSV came from the marine environment: Clues from the literature, or just red herrings? Bull Eur Assoc Fish Pathol 19:60-65

Dixon PF, Feist S, Kehoe E, Parry L, Stone DM, Way K (1997) Isolation of viral haemorrhagic septicaemia virus from Atlantic herring Clupea harrengus from the English Channel. Dis Aquat Org 30:81-89

Dopazo CP, Bandín I, López-Vasquez C, Lamas J, Noya M, Barja JL (2002) Isolation of viral hemorrhagic septicaemia virus from Greenland halibut Reinhardtius hippoglossoides caught at the Flemish Cap. Dis Aquat Org 50: 171-179

Einer-Jensen $\mathrm{K}$, Olesen NJ, Lorenzen N, Jørgensen PEV (1995) Use of the polymerase chain reaction (PCR) to differentiate serologically similar viral haemorrhagic septicaemia (VHS) virus isolates from Europe and America. Vet Res 26:464-469

Fijan N, Sulimanovic D, Bearzotti M, Muzinic D, Zwillenberg LO, Chilmonczyk S, Vautherot JF, de Kinkelin P (1983) Some properties of the epithelioma papulosum cyprini (EPC) cell line from carp Cyprinus carpio. Ann Virol 134: 207-220

Hart JL (1973) Pacific fishes of Canada. Bulletin 180, Fisheries Research Board of Canada, Ottawa

Hershberger PK, Kocan RM, Elder NE, Meyers TR, Winton JR (1999) Epizootiology of viral hemorrhagic septicemia virus in Pacific herring from the spawn-on-kelp fishery in Prince William, Alaska, USA. Dis Aquat Org 44:75-78

Huang C, Chien MS, Landolt M, Batts W, Winton J (1996) Mapping the neutralizing epitopes on the glycoprotein of infectious haematopoietic necrosis virus, a fish rhabdovirus. J Gen Virol 77:3033-3040

Hyatt AD, Hine PM, Jones JB,Whittington RJ, Kearns C, Wise TG, Crane MS, Williams LM (1997) Epizootic mortality in the pilchard (Sardinops sagax neopilchardus) in Australia and New Zealand in 1995. II. Identification of a herpesvirus within the gill epithelium. Dis Aquat Org 28:17-29

Jensen NJ, Bloch B, Larsen JL (1979) The ulcus syndrome in cod (Gadus morhua). III. A preliminary virological report. Nord Veterinaermed 31:436-442

Jørgensen PEV, Einer-Jensen $\mathrm{K}$, Higman $\mathrm{KH}$, Winton JR (1995) Sequence comparison of the central region of the glycoprotein gene of neutralizable, non-neutralizable, and serially passed isolates of viral haemorrhagic septicaemia virus. Dis Aquat Org 23:77-82

Kent ML, Traxler GS, Kieser D, Richard J and 5 others (1998) Survey of salmonid pathogens in ocean-caught fishes in British Columbia, Canada. J Aquat Anim Health 10: 211-219

King JA, Snow M, Kall HF, Raynard RS (2001) Experimental susceptibility of Atlantic salmon Salmo salar and turbot Scopthalmus maximus to European freshwater and marine isolates of viral haemorrhagic septicaemia virus. Dis Aquat Org 47:25-31

Kocan R, Bradley M, Elder, N, Meyers T, Batts W, Winton JR (1997) North American strain of viral hemorrhagic sep- 
ticemia virus is highly pathogenic for laboratory-reared Pacific herring. J Aquat Anim Health 9:279-290

Kocan RM, Hershberger PK, Elder NE, Winton JR (2001a) Epidemiology of viral hemorrhagic septicemia among juvenile Pacific herring and Pacific sand lances in Puget Sound, Washington. J Aquat Anim Health 13:77-85

Kocan RM, Hershberger PK, Elder NE (2001b) Survival of the North American strain of viral hemorrhagic septicemia virus (VHSV) in filtered seawater and seawater containing ovarian fluid, crude oil and serum-enriched culture medium. Dis Aquat Org 44:75-78

Konno ES, Wolf P, Bergen DR (2001) Pacific mackerel. In: Leet WS, Dewees CM, Klingbeil R, Larson EJ (eds) California's living marine resources: a status report. Dept of Fish and Game, University of California, Oakland, p 306-308

Lannan CN, Winton JR, Fryer JL (1984) Fish cell lines: establishment and characterization ofnine cell lines from salmonids. In Vitro 20:671-676

Marty GD, Freiberg EF, Meyers TR, Wilcock J, Farver TB, Hinton DE (1998) Viral hemorrhagic septicemia virus, Ichthyophonus hoferi, and other causes of morbidity in Pacific herring (Clupea pallasi) spawning in Prince William Sound, Alaska, USA. Dis Aquat Org 32:14-40

Meier W, Schmitt M, Wahli T (1994) Viral hemorrhagic septicemia (VHS) of nonsalmonids. Annu Rev Fish Dis 4: 359-373

Meyers TR, Winton JR (1995) Viral hemorrhagic septicemia virus in North America. Annu Rev Fish Dis 5:3-24

Meyers TR, Sullivan J, Emmenegger E, Follett J, Short S, Batts WN, Winton JR (1992) Identification of viral hemorrhagic septicemia virus isolated from Pacific cod Gadus macrocephalus in Prince William Sound, Alaska, USA. Dis Aquat Org 12:167-175

Meyers TR, Short S, Lipson K, Batts WN, Winton JR, Wilcock J, Brown E (1994) Association of viral hemorrhagic septicemia virus with epizootic hemorrhages of the skin in Pacific herring Clupea harengus pallasi from Prince William Sound and Kodiak Island, Alaska, USA. Dis Aquat Org 19:27-37

Meyers TR, Short S, Lipson K (1999) Isolation of the North American strain of viral hemorrhagic septicemia virus (VHSV) associated with epizootic mortality in two new host species of Alaskan marine fish. Dis Aquat Org 38: 81-86

Mortensen HF, Heuer OE, Lorenzen N, Otte L, Olesen NJ (1999) Isolation of viral haemorrhagic septicaemia virus (VHSV) from wild marine fish species in the Baltic Sea, Kattegat, Skagerrak and the North Sea. Virus Res 63: 95-106

Nishizawa $T$, Iida $H$, Takano $R$, Isshiki $T$, Nakajima $K$, Muroga K (2002) Genetic relatedness among Japanese, American and European isolates of viral hemorrhagic septicemia virus (VHSV) based on partial G and P genes. Dis Aquat Org 48:143-148

OIE (Office International des Epizooties) (2000) Diagnostic manual for aquatic animal diseases, 3rd edn. OIE, Paris

Editorial responsibility: Jo-Ann Leong,

Kaneohe, Hawaii, USA
Parry L, Dixon PF (1979) Stability of nine viral haemorrhagic septicaemia virus (VHSV) isolates in seawater. Bull Eur Assoc Fish Pathol 17:31-36

Ross K, McCarth U, Huntly PJ, Wood BP, Stuart E, Rough EI, Smail DA, Bruno DW (1994) An outbreak of viral haemorrhagic septicaemia (VHS) in turbot (Scophthalmus maximus) in Scotland. Bull Eur Assoc Fish Pathol 14:213-214

Schaefer MB (1936) Contribution of the life history of the surf smelt Hypomesus pretiosus in Puget Sound, WA. Dept Fish Biol Rep 35B:1-45

Smail DA (1999) Viral haemorrhagic septicaemia. In: Woo PTK, Bruno DW (eds) Fish diseases and disorders, Vol 3. Viral, bacterial and fungal infections. CAB International, New York, p 123-147

Snow M, Cunningham CO, Melvi WT, Kurath G (1999) Analysis of the nucleoprotein gene identifies distinct lineages of viral haemorrhagic septicaemia virus within the European marine environment. Virus Res 63:35-44

Stocker M (2001) Fish stocks of the Pacific coast. Fisheries and Oceans Canada, Ottawa

Stone DM, Way K, Dixon PF (1997) Nucleotide sequence of the glycoprotein gene of viral haemorrhagic septicaemia (VHS) viruses from different geographical areas: a link between VHS in farmed fish species and viruses isolated from North Sea cod (Gadus morhua L.). J Gen Virol 78: $1319-1326$

Sweetnam DA, Baxter RD, Moyle PB (2001) True smelts. In: Leet WS, Dewees CM, Klingbeil R, Larson EJ (eds) California's living marine resources: a status report. Dept of Fish and Game, University of California Press, Oakland, p $477-478$

Takano R, Mori K, Nishizawa T, Arimoto M, Muroga K (2001) Isolation of viruses from wild Japanese flounder, Paralichthys olivaceus. Fish Pathol 36(3):153-160

Thoesen J (1994) Suggested procedures for the detection and identification of certain finfish and shellfish pathogens, 4th edn. Fish Health Section, American Fisheries Society, Bethesda, MD

Whittington RJ, Jones B, Hine PM, Hyatt A (1997) Epizootic mortality in the pilchard (Sardinops sagax neopilchardus) in Australia and New Zealand in 1995. I. Pathology and epizootiology. Dis Aquat Org 28:1-15

Winton JR, Einer-Jensen K (2002) Molecular diagnosis of infectious hematopoietic necrosis and viral hemorrhagic septicemia. In: Cunningham CO (ed) Molecular diagnosis of salmonid diseases. Kluwer, Dordrecht, p 49-79

Winton JR, Batts WN, Deering RE, Brunson R, Hopper K, Nishizawa T, Stehr C (1991) Characteristics of the first North American isolates of viral hemorrhagic septicemia virus. In: Proc 2nd Int Symp Viruses of Lower Vertebrates. Corvallis, Oregon, July 29-31, 1991. Oregon State University Press, Corvallis, OR, p 43-50

Wolf P, Smith PE, Bergen DR (2001) Pacific sardine. In: Leet WS, Dewees CM, Klingbeil R, Larson EJ (eds) California's living marine resources: a status report. Dept of Fish and Game, University of California Press, Oakland, p 299-302

Submitted: October 26, 2002; Accepted: April 11, 2003

Proofs received from author(s): July 10, 2003 